\title{
ALK Inhibitors in Nonsmall Cell Lung Cancer
}

\author{
Nitish Garg ${ }^{1}$ Rushabh Kothari \\ ${ }^{1}$ Vydehi Institute of Medical Sciences and Research Center, \\ Bengaluru, Karnataka, India \\ ${ }^{2}$ Cancure Cancer Center, Narayana Multispeciality Hospital, \\ Ahmedabad, Gujarat, India
}

Ind J Med Paediatr Oncol 2021;42:67-70.

The management of advanced nonsmall cell lung cancer (NSCLC) has gone a definitive change over time with the discovery of small-molecule inhibitors. In 2004, the first initial description of actionable mutation of epidermal growth factor receptor (EGFR) was provided, and since then, almost 10 actionable mutations have been identified. ${ }^{1}$ These include EGFR, anaplastic lymphoma kinase (ALK), ROS, MET, rearranged during transfection (RET), Kirsten rat sarcoma viral oncogene (KRAS), raf murine sarcoma virus oncogene homo$\log \mathrm{B}$ (BRAF), and many others. After the development of the drugs against these receptors, these were approved by US Food and Drug Administration (FDA) for used against NSCLC with the receptor mutations.

The most common receptor tyrosine kinase mutations in adenocarcinoma lung are as follows: ${ }^{2}$

1. KRAS mutation in $25 \%$ of cases of NSCLC

2. EGFR mutation-10 to $30 \%$

3. MET amplification or MET exon 14 mutation-5\%

4. ALK mutation-3 to $7 \%$ cases

5. BRAF mutations -2 to $4 \%$

6. Rest others: RET rearrangements, MEK1 mutation, FGFR1 amplification, Her2 mutation, ROS1 rearrangements, and NRAS mutation occur in $1 \%$ each

7. The majority are still unknown-40\%.

The drugs are very effective for patients with actionable mutant NSCLC with the response rates of 60 to $85 \%$ in the first-line setting. The main barrier is the development of resistance after a few months of treatment, which limits the duration of response to $\sim 1$ to 2 years for most of the drugs. ${ }^{3}$

\section{Anaplastic Lymphoma Kinase Rearrangements}

ALK being the first reported oncogene in NSCLC in 2007 is usually found fused to echinoderm microtubule-associated protein-like 4 (EML4) gene, leading to its permanent
Address for correspondence Nitish Garg, MBBS, MD, DNB (General Medicine), Vydehi Hospital, \#82 EPIP, Nallurahalli, Whitefield, Bengaluru, Karnataka 560066, India (e-mail: nitish_jeenu@yahoo.co.in).

activation, and hence, leading to cellular proliferation. The other fusion loci are TFG, KIF5B, and KLC1.4-8

It is detected in 3 to $7 \%$ cases of NSCLC and seen in younger patients who are light or never smokers, and their presentation is usually at the advanced stage. ${ }^{8}$ Since 2007, small-molecule ALK tyrosine kinase inhibitors (TKIs) are being developed and are found to be highly sensitive in ALK-rearranged NSCLC.

Diagnostic tools for targeted mutation in carcinoma lung: ${ }^{9}$

1. Fluorescence in situ hybridization (FISH) analysis: It is the gold standard technique for ALK mutation testing. Vysis ALK break apart FISH probe kit manufactured by Abbot was approved by FDA for the use in 2011. The probe has two fluorophores-red binding to 3' end of ALK gene and green binding to $5^{\prime}$ end. When the translocation is seen, the probe shows separated red and green fluorophores, or has loss of the green signal, but we have to examine $15 \%$ or more cells for the mutation to be labeled as positive.

The demerits of FISH are as follows: (1) costly, (2) it requires expert and experienced pathologist for interpretation, (3) provides information only about the translocation of ALK gene and not about the fusion partners, and (4) is time-consuming. However, it is very accurate and detects all the ALK rearrangements.

2. Immunohistochemistry (IHC): ALK can be readily identified by IHC, but the protein levels in NSCLC are lower compared with anaplastic large-cell lymphoma that makes it difficult to attempt. The antibodies commonly used are D5F3, ALK clone ZAL4, and 5A4, and in India, we are commonly using D5F3 antibodies. It is still not a preferred method because of the problems faced during tissue preparation, antibody choice, signal enhancement systems, and the optimal scoring system, which are not standardized as yet. It is helpful because of low cost, easy to be performed and interpreted by pathologist, quick results and with the background histological information.
DOI https://doi.org/ $10.1055 / \mathrm{s}-0041-1729728$ ISSN 0971-5851
(C) 2021. Indian Society of Medical and Paediatric Oncology This is an open access article published by Thieme under the terms of the Creative Commons Attribution-NonDerivative-NonCommercial-License, permitting copying and reproduction so long as the original work is given appropriate credit. Contents may not be used for commercial purposes, or adapted, remixed, transformed or built upon. (https://creativecommons.org/licenses/by-nc-nd/4.0/). Thieme Medical and Scientific Publishers Pvt. Ltd. A-12, 2nd Floor, Sector 2, Noida-201301 UP, India 
Other problem with IHC is the discordant results went compared with FISH, which are in the range of 1 to $10 \%$. This problem may be due to intrachromosomal translocations that are not detected on FISH and the patients are labeled as IHC+/FISH-ve. These patients when treated with crizotinib show similar objective response rate (ORR) and disease control rate as compared with FISH positive patient in PROFILE
1001 trial. Hence, IHC+/FISH-ALK-positive patients can still be treated with ALK TKIs. ${ }^{10}$

3. Polymerase chain reaction (PCR) by either reverse transcriptase or 5' rapid amplification of cDNA ends-PCR helps finding out the fusion protein when specific primers are added. It helps in identifying DNA from a diluted sample with good sensitivity and specificity. However, PCR fails

Table 1 Anaplastic lymphoma kinase inhibitors with their properties and evidence

\begin{tabular}{|c|c|c|c|c|c|c|}
\hline Drug & Gen & Dose & RR & PFS (months) & AEs & Evidence \\
\hline Crizotinib & $1 \mathrm{st}$ & $\begin{array}{l}250 \text { mg twice a } \\
\text { day (with/with- } \\
\text { out food) }\end{array}$ & $\begin{array}{l}74 \% \text { (1st line) } \\
65 \% \text { ( } 2 \text { nd } \\
\text { line) }\end{array}$ & $\begin{array}{l}10.9 \text { (1st line) } 7.7 \\
\text { (2nd line) }\end{array}$ & $\begin{array}{l}\text { Visual disturbances } \\
\text { Transaminitis } \\
\text { Nausea/vomiting } \\
\text { Diarrhea/abdominal pain } \\
\text { Cytopenia } \\
\text { Fatigue } \\
\text { Edema } \\
\text { Hypophosphatemia } \\
\text { QTc prolongation } \\
\text { Renal cysts }\end{array}$ & $\begin{array}{l}\text { PROFILE1014 } \\
\text { (1st line) } \\
\text { PROFILE1007 } \\
\text { (2nd line) }\end{array}$ \\
\hline Ceritinib & 2nd & $\begin{array}{l}750 \mathrm{mg} \text { fasting } \\
\text { or } 450 \mathrm{mg} \text { with } \\
\text { food }^{19}\end{array}$ & $\begin{array}{l}72.5 \%(1 s t \\
\text { line) }\end{array}$ & $\begin{array}{l}26.3 \text { (no brain } \\
\text { mets:1st line) } \\
16.6 \text { (brain } \\
\text { mets: } 1 \text { st line) } \\
5.4 \text { ( } 2 \text { nd line) }\end{array}$ & $\begin{array}{l}\text { Transaminitis } \\
\text { Nausea/vomiting } \\
\text { Diarrhea/abdominal pain } \\
\text { Cytopenia } \\
\text { Hyperglycemia } \\
\text { Hypophosphatemia } \\
\text { Fatigue } \\
\text { Increased creatinine } \\
\text { QTc prolongation }\end{array}$ & $\begin{array}{l}\text { ASCEND- }{ }^{20} \text { ASCEND }-5^{21} \\
\text { (both } 2 \text { nd line) } \\
\text { ASCEND-422 } \\
\text { (1st Line) }\end{array}$ \\
\hline Alectinib & 2nd & $\begin{array}{l}600 \mathrm{mg} \text { twice a } \\
\text { day after food }\end{array}$ & $92 \%$ (1st line) & $\begin{array}{l}25.7 \text { (1st line) } \\
7.5-11 \text { (2nd line, } \\
\text { postcrizotinib) }\end{array}$ & $\begin{array}{l}\text { LFT derangement } \\
\text { Cytopenia } \\
\text { Elevated CPK } \\
\text { Hyperglycemia } \\
\text { Hyponatremia } \\
\text { Hypophosphatemia } \\
\text { Raised creatinine } \\
\text { Bradycardia } \\
\text { Fatigue } \\
\text { Edema } \\
\text { Constipation }\end{array}$ & $\begin{array}{l}\text { J-ALEX } \\
\text { Global ALEX }{ }^{25} \\
\text { (1st line) }\end{array}$ \\
\hline Brigatinib & 2nd & $\begin{array}{l}90 \text { mg for } 7 \\
\text { days than } 180 \\
\text { mg once a day } \\
\text { (with/without } \\
\text { food) }\end{array}$ & $\begin{array}{l}54 \% \text { in } \\
\text { crizotinib } \\
\text { refractory }\end{array}$ & 12.9 (1st line) & $\begin{array}{l}\text { Early ILD } \\
\text { Transaminitis } \\
\text { Hyperglycemia } \\
\text { Hypertension } \\
\text { Bradycardia } \\
\text { Fatigue } \\
\text { Nausea } \\
\text { Diarrhea } \\
\text { Headache } \\
\text { Increased CPK }\end{array}$ & $\begin{array}{l}\text { ALTA phase II } \\
\text { trial }^{26}\end{array}$ \\
\hline Lorlatinib & $3 r d$ & $\begin{array}{l}100 \text { mg once a } \\
\text { day (with/with- } \\
\text { out food) }\end{array}$ & $\begin{array}{l}46 \% \text { in heavily } \\
\text { pretreated } \\
\text { patients }\end{array}$ & $\begin{array}{l}11.4 \text { and has high CNS } \\
\text { penetration unlike } \\
\text { other P-gp } \\
\text { drugs }^{13}\end{array}$ & $\begin{array}{l}\text { Hypercholesterolemia } \\
\text { Hypertriglyceridemia } \\
\text { Edema } \\
\text { Neurocognitive dysfunction } \\
\text { Mood lability } \\
\text { Peripheral neuropathy } \\
\text { Second-degree AV block or } \\
\text { Complete heart blocks } \\
\text { Interstitial lung disease } \\
\text { Contraindicated when } \\
\text { strong CYP } \\
\text { P450 inducers are used }\end{array}$ & \\
\hline
\end{tabular}

Abbreviations: AE, adverse effect; AV, atrioventricular; CNS, central nervous system; CPK, creatine phosphokinase; CYP, cytochrome P450; Gen, generation; ILD, interstitial lung disease; LFT, liver function test; PFS, progression-free survival; p-gp, glycoprotein-P; RR, response rate. 
to identify unknown fusions or novel fusions affected by sample contamination and quality of sample.

4. Next-generation sequencing: The technique of genomic profiling of the sample DNA to identify the ALK mutation or fusions missed by FISH. It can identify complex rearrangements in the genome and helps in identifying the mutations in patients who are IHC positive and FISH negative. It helps in the diagnosis of driver mutations not identified by other methods, but is time-consuming and costly.

3. Exon-array profiling can be used for the detection of alk-eml4 fusion by the expression of transcripts at 3' and 5 ' end of ALK gene. The details of ALK inhibitors are given with evidence in - Table 1.

\section{Resistance Mechanism}

\section{First Generation}

Usually, patients experience progression after 1 to 2 years of treatment. About 20 to $30 \%$ cases of resistance to first-line ALK inhibitors are due to ALK tyrosine kinase domain facing steric hindrance at the adenosine 5 '-triphosphate binding site (L1196M-analog of T790M of EGFR). At progression, as only 20 to 30\% ALK-positive NSCLC will have ALK TDK mutations after the use of crizotinib, compared with EGFR where it is in range of $60 \%$. Hence, the reassessment with repeat biopsy or circulating free DNA is not required in ALK positive cases progressed on first-line ALK inhibitors.

The other mechanisms are mutation in solvent-exposed kinase region binding site (G1202R) and 1151Tins, ALK amplification leading to single-crystal fibers amplifications, and bypass pathways such as EGFR, MET, and KRAS. Even in few cases, histological transformation may be a cause known as epithelial to mesenchymal transition. Among these ALK mutations, $10 \%$ cases are where ALK amplification leads to the resistance to crizotinib. ${ }^{11,12}$

\section{Second Generation}

In the second-generation, ALK TKI's most important mechanism is a change in the ALK kinase domain or the solvent-exposed kinase region.

However, still certain studies have found patients acquiring compound mutations over time.

Other off-target pathways are the same as the first-generation drugs. The therapy and sequencing of ALK inhibitors for ALK positive NSCLC are shown in - Fig. 1.

\section{Newer Anaplastic Lymphoma Kinase Small Molecules}

1. Lorlatinib-Dual ALK and ROS1 inhibitor and active against most of the ALK resistance mutations. It is even used in the combination when patients are found to be having compound mutations. This third-generation ALK TKI is a low efflux substrate of P-gp and hence has high central nervous system (CNS) penetration and activity, even in highly pretreated patients with $>1$ ALK TKIs. Lorlatinib showed ORR of $46 \%$ and PFS of 11.4 months in phase I of phase I/II clinical trial and ORR of $42 \%$ and PFS of 9.2 months in patient treated with $>2$ lines of ALK inhibitors. ${ }^{13}$ The recommended dose is $100 \mathrm{mg}$ once a day and major Grade 3 adverse effects (AEs) are hypercholesterolemia, hypertriglyceridemia, and edema that are most commonly seen. Reversible CNS side effects are neurocognitive disorders, mood lability, and peripheral neuropathy. Combined mutations have shown to cause resistance to lorlatinib than single-gene mutations, for example, C1156Y+L1198F. Mutation to third-generation ALK inhibitors occur due to complex mechanism and not due to acquisition of secondary mutations in ALK-EM4. These mutations occur due to activation of by-pass mechanisms like loss of NF2 or EMT, this mechanism is called loss of ALK dependency, and compound mutations. ${ }^{14,15}$

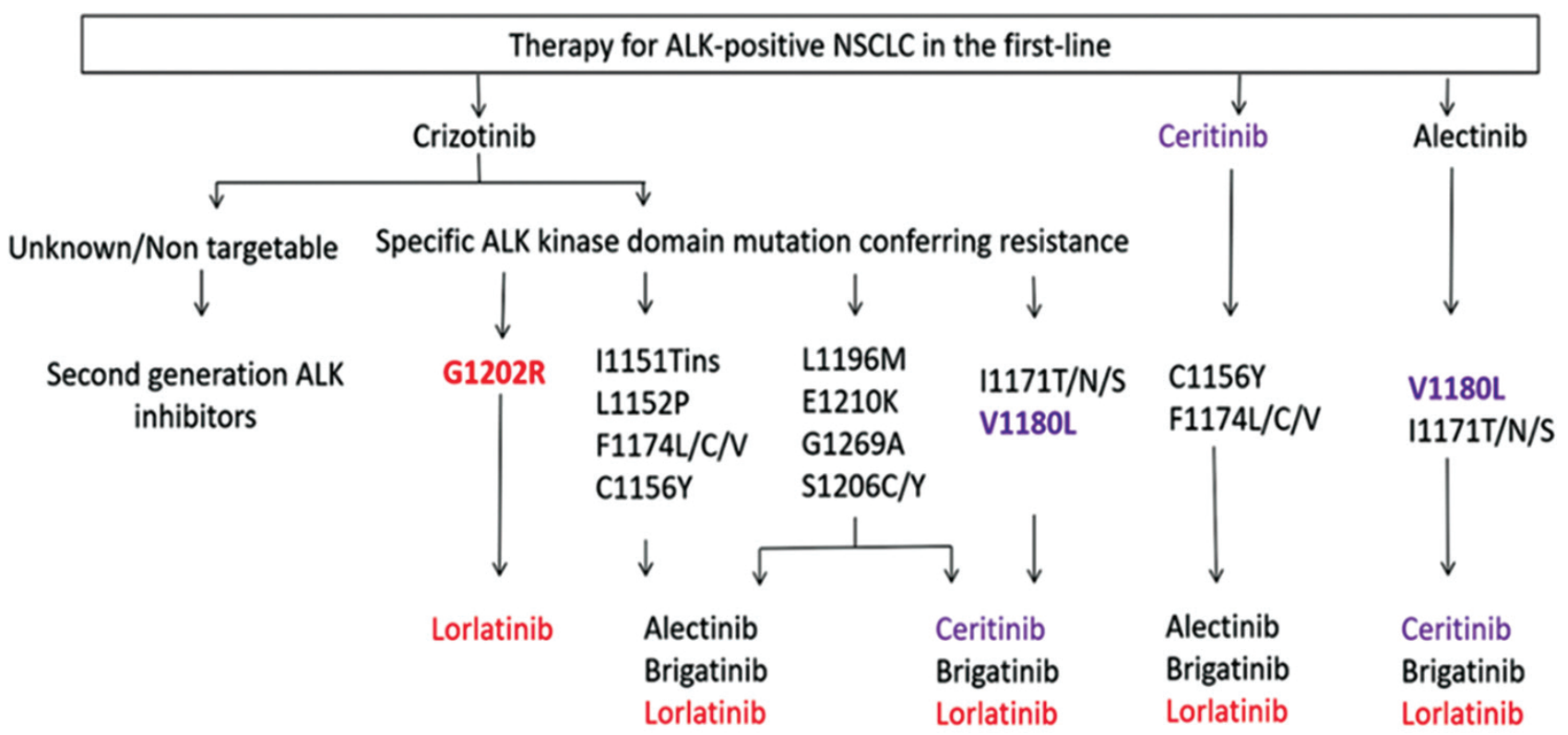

Fig. 1 Therapy for anaplastic lymphoma kinase positive nonsmall cell lung cancer at progression guided by the next-generation sequencing. ${ }^{27}$ 
2. Ensartinib-Another third-generation molecule with activity against-ALK, ROS1, MET, AXL. It has good CNS penetration. In phase II trials, responses shown are $77 \%$ in crizotinib naïve and $73 \%$ in crizotinib-treated patients. ${ }^{16}$ The dose recommended is $225 \mathrm{mg}$ once a day till progression or unacceptable toxicities. Most common AEs are mild rash, nausea, vomiting, fatigue, and pruritus.

3. Repotrectinib (known as TPX-0005)-It has activity against ALK, ROS, and TRK kinases. It was specially designed to overcome G1202R mutation but is affective against SRC amplification and FAC mutations. It is undergoing phase I study at present.

\section{Financial Support and Sponsorship \\ Nil.}

\section{Conflict of Interest}

There are no conflict of interest.

\section{References}

1 Lynch TJ, Bell DW, Sordella R, et al. Activating mutations in the epidermal growth factor receptor underlying responsiveness of non-small-cell lung cancer to gefitinib. N Engl J Med 2004;350(21):2129-2139

2 Lin JJ, Shaw AT. Resisting resistance: targeted therapies in lung cancer. Trends Cancer 2016;2(7):350-364

3 Swanton C, Govindan R. Clinical implications of genomic discoveries in lung cancer. N Engl J Med 2016;374(19):1864-1873

4 Soda M, Choi YL, Enomoto M, et al. Identification of the transforming EML4-ALK fusion gene in non-small-cell lung cancer. Nature 2007;448(7153):561-566

5 Rikova K, Guo A, Zeng Q, et al. Global survey of phosphotyrosine signaling identifies oncogenic kinases in lung cancer. Cell 2007;131(6):1190-1203

6 Takeuchi K, Choi YL, Togashi Y, et al. KIF5B-ALK, a novel fusion oncokinase identified by an immunohistochemistry-based diagnostic system for ALK-positive lung cancer. Clin Cancer Res 2009;15(9):3143-3149

7 Togashi Y, Soda M, Sakata S, et al. KLC1-ALK: a novel fusion in lung cancer identified using a formalin-fixed paraffin-embedded tissue only. PLoS One 2012;7(2):e31323

8 Shaw AT, Yeap BY, Mino-Kenudson M, et al. Clinical features and outcome of patients with non-small-cell lung cancer who harbor EML4-ALK. J Clin Oncol 2009;27(26):4247-4253

9 Shackelford RE, Vora M, Mayhall K, Cotelingam J. ALKrearrangements and testing methods in non-small cell lung cancer: a review. Genes Cancer 2014;5(1-2):1-14

10 Zanwar S, Noronha V, Joshi A, et al. Efficacy of crizotinib in ALK mutant non-small cell lung cancers that are positive by IHC but negative by FISH compared to FISH positive cases. Indian J Cancer 2017;54(4):678-680

11 Choi YL, Soda M, Yamashita Y, et al. ALK Lung Cancer Study Group. EML4-ALK mutations in lung cancer that confer resistance to ALK inhibitors. N Engl J Med 2010;363(18):1734-1739

12 Katayama R, Shaw AT, Khan TM, et al. Mechanisms of acquired crizotinib resistance in ALK-rearranged lung Cancers. Sci Transl Med 2012;4(120):120ra17
13 Solomon BJ, Bauer TM, Felip E, et al. Safety and efficacy of lorlatinib (PF-06463922) from the dose escalation component of a study in patients with advanced ALK+ or ROS1+ non-small cell lung cancer (NSCLC) J Clin Oncol 2016;34(suppl) :9009-9009

14 Gainor JF, Dardaei L, Yoda S, et al. Molecular mechanisms of resistance to first- and second-generation ALK inhibitors in ALK-rearranged lung cancer. Cancer Discov 2016; 6(10):1118-1133

15 Recondo G, Mezquita L, Facchinetti F, et al. Diverse resistance mechanisms to the third-generation ALK inhibitor lorlatinib in ALK-rearranged lung cancer. Clin Cancer Res 2020;26(1):242-255

16 Kim DW, Mehra R, Tan DSW, et al. Activity and safety of ceritinib in patients with ALK-rearranged non-small-cell lung cancer (ASCEND-1): updated results from the multicentre, open-label, phase 1 trial. Lancet Oncol 2016;17(4):452-463

17 Solomon BJ, Mok T, Kim DW, et al. PROFILE 1014 Investigators. First-line crizotinib versus chemotherapy in ALK-positive lung cancer. N Engl J Med 2014;371(23):2167-2177

18 Shaw AT, Kim DW, Nakagawa K, et al. Crizotinib versus chemotherapy in advanced ALK-positive lung cancer. N Engl J Med 2013;368(25):2385-2394

19 Cho BC, Kim DW, Bearz A, et al. ASCEND-8: A randomized phase 1 study of ceritinib, $450 \mathrm{mg}$ or $600 \mathrm{mg}$, taken with a low-fat meal versus $750 \mathrm{mg}$ in fasted state in patients with anaplastic lymphoma kinase (ALK)-rearranged metastatic non-small cell lung cancer (NSCLC) J Thorac Oncol 2017;12(9):1357-1367

20 Shaw AT, Kim DW, Mehra R, et al. Ceritinib in ALK-rearranged non-small-cell lung cancer. N Engl J Med 2014;370(13): 1189-1197

21 Shaw AT, Kim TM, Crinò L, et al. Ceritinib versus chemotherapy in patients with ALK-rearranged non-small-cell lung cancer previously given chemotherapy and crizotinib (ASCEND-5): a randomised, controlled, open-label, phase 3 trial. Lancet Oncol 2017;18(7):874-886

22 Soria JC, Tan DSW, Chiari R, et al. First-line ceritinib versus platinum-based chemotherapy in advanced ALK-rearranged nonsmall-cell lung cancer (ASCEND-4): a randomised, open-label, phase 3 study. Lancet 2017;389(10072):917-929

23 Shaw AT, Gandhi L, Gadgeel S, et al. study investigators. Alectinib in ALK-positive, crizotinib-resistant, non-small-cell lung cancer: a single-group, multicentre, phase 2 trial. Lancet Oncol 2016;17(2):234-242

24 Ou SH, Ahn JS, De Petris L, et al. Alectinib in crizotinib-refractory ALK-rearranged non-small-cell lung cancer: A Phase II global study. J Clin Oncol 2016;34(7):661-668

25 Hida T, Nokihara $\mathrm{H}$, Kondo $\mathrm{M}$, et al. Alectinib versus crizotinib in patients with ALK-positive non-small-cell lung cancer (J-ALEX): an open-label, randomised phase 3 trial. Lancet 2017;390(10089):29-39

26 Kim DW, Tiseo M, Ahn MJ, et al. Brigatinib in patients with crizotinib-refractory anaplastic lymphoma kinase-positive non-small-cell lung cancer: A randomized, multicenter phase ii trial. J Clin Oncol 2017;35(22):2490-2498

27 Kapoor A, Noronha V, Shetty O, et al. Molecular tumor board: case2- Evolution of resistance in anaplastic lymphoma kinase driven non-small cell lung carcinoma. Cancer Res Stat Treat 2020;3:89-92 